\title{
Maurycy Pius Rudzki and the birth of geophysics
}

\author{
Antoni Jackowski and Kazimierz Krzemień \\ Jagiellonian University, Institute of Geography and Spatial Management, ul. Gronostajowa 7, \\ 30-387 Kraków, Poland \\ Correspondence to: Kazimierz Krzemień (kazimierz.krzemien@uj.edu.pl)
}

Received: 20 November 2015 - Revised: 15 January 2016 - Accepted: 26 January 2016 - Published: 25 February 2016

\begin{abstract}
The article describes briefly the life and fundamental work of Rudzki in geology, geography, seismology, oceanography and meteorology. In 1895 he became head of the world's first department of geophysics and meteorology at the Jagiellonian University of Kraków, the second oldest university north of the Alps (Prague being the oldest).
\end{abstract}

\section{Introduction}

Maurycy Pius Rudzki (1862-1916), a Polish geophysicist and geographer, was born on 28 December 1862 in Uhryńkowce (Czortkowski powiat in the Podole region, present-day Ukraine) to Pius Rudzki and Teofila Anna Brunicka, a family of wealthy landed gentry. He spent his childhood and youth in Podole. Maurycy Pius Rudzki passed his baccalaureate exam in June 1882 at Kamieniec Podolski (present-day Ukraine). In the same year he enrolled at the Lviv University Department of Geography, under Professor A. Rehman. A year later, he moved on to Vienna, where he studied the natural science subjects of geography and geology (including palaeontology and petrography), which he complemented with advanced courses in mathematics, physics and astronomy. He received his PhD on 1 December 1886 for his thesis on the geology of the Silurian series in the Galician Podole region. In this study he pioneered the use of higher mathematics and physics in the investigation of the physics of the Earth, a method that was regarded as groundbreaking and innovative (Brzozowski 1991/1992; Dormus, 1996, 2011, 2013; Garlicka, 1994; Maj, 1988; Rybka, 1974; Wójcik, 1988). At the time, Rudzki was already interested in the overall structure of the Earth about which he produced the following publications: O stanie wnestrza Ziemi (On the status of the Earth's interior) (1889), Skorupa Ziemi (The Earth's crust) (1890), and Nieskolko zamieczanji po powodu teorii obrazowanja gor (A few comments on the theory of mountain formation) (1890). That last of the three studies was probably the basis for his receiving an MA in geography in Kharkiv, Russia (1890), the equivalent of a PhD in other countries. Between 1891 and 1895, M. P. Rudzki was employed as a docent (PhD hab.) at the University of Odessa (Maj, 1996). His work went substantially beyond the framework of classical descriptive geography and geology as he gradually moved away from geography and geology towards geophysics. His areas of interest included the global distribution of continents and their movement during the ice age, sea level oscillation, the theory of the Earth's physical state, Earth tectonics, Earth physics, meteorology and fluvial studies. Rudzki was particularly drawn into the study of the inner structure of the Earth and the age of the planet and published a string of papers on these issues. He was also fascinated by seismology, a new discipline that emerged in Germany and Japan in the late 19th century.

In 1894, Kraków's Jagiellonian University made a request to the central educational authorities in Vienna (Kraków belonged to the Austro-Hungarian Empire at that time) for permission to open a department of geophysics, while at the same time asking the University of Odessa's permission for docent Rudzki to take charge of the new unit add (Hanik, 1986; Jackowski and Sołjan, 2009). On 1 November 1895, Rudzki was appointed Professor of Mathematical Geophysics and Meteorology of the Jagiellonian University and nominated as the head of the world's first department of mathematical geophysics and meteorology (The next such department would open three years later in Göttingen.). For details about the historical development of the term geophysics refer to the article of Buntebarth in Good (1998); 


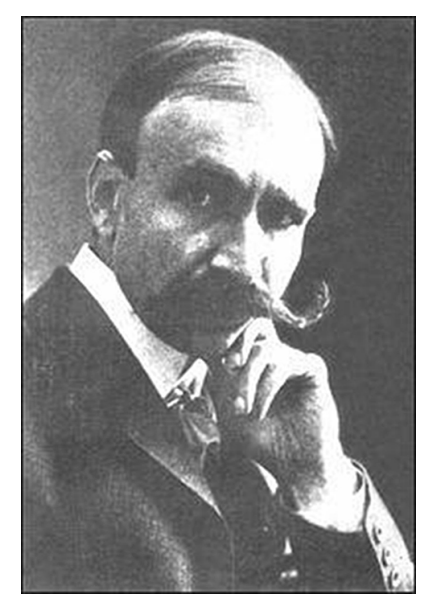

Figure 1. Photo of Maurycy Pius Rudzki.

about the early history of geophysics refer to the article of Kertz in Good (1998) or to Schröder (2010).

The professor arrived in Kraków in the spring of 1896 and began teaching immediately. Some of the courses offered at the new department included meteorology, Earth physics and periodically also cartography. On 15 June 1901, Professor Rudzki received the title of full professor of mathematical geophysics and meteorology. On 1 October 1902, he took the helm of the university's astronomical observatory and received full professorship of Astronomy and Geophysics. In that capacity he procured the first seismographs in Kraków. In 1903, Rudzki established a seismological station in Kraków, which was the region's first such station and one of very few in Europe at the time (e.g. Guidoboni, 2009; Mazur, 2007; Teisseyre, 1996). In 1904, he launched an annual bulletin Resultate der meteorologischen, seismologischen und magnetischen Beobachtungen an der k.k. Sternwarte in Krakau (Results of meteorological, seismologic and magnetic observations of the imperial and royal observatory of Kraków). Many of his publications combined aspects of geophysics, geology and physical geography, while meteorology was another strand of his publishing activity (Ołpińska-Warzechowa, 1996; Staszewski, 1962). Rudzki was also instrumental in the establishment of a weather station in Zakopane in July 1911. As the Chairman of the Meteorological Section of the Physiography Commission of the Kraków Scientific Society (Sekcja Meteorologiczna Komisji Fizjograficznej Krakowskiego Towarzystwa Naukowego), he gave his support to the Natural Science Section of the Tatra Society (Sekcja Przyrodnicza Towarzystwa Tatrzańskiego) in their efforts to establish the station and produced, together with Leon Grabowski of Lviv University), guidelines for its specification.

Two studies by Rudzki are particularly valued by geographers, i.e. Fizyka Ziemi (Geophysics) (Kraków, 1909) and Zasady meteorologii (Principles of Meteorology) (Warsaw, 1917, one year after his death). At the time, Fizyka Ziemi
(Geophysics) had no counterpart worldwide and received an award from Polish Academy of Arts and Sciences, the predecessor of the Polish Academy of Sciences. The section of the book devoted to oceanography was particularly innovative, and science historians now claim that this was the world's first-ever study in dynamic oceanography based on the physics of the sea. Sadly, contemporary Polish geographers failed to appreciate the importance of his book. It became known to the international academic community only after the author published his own German translation of a revised version with new insights and observations (Leipzig, 1911). The book then went on to become a standard textbook for generations of geophysicists. Similarly, his meteorology book was before its time, attracting little attention from his contemporaries, even if it was regarded as "presenting a much higher quality than similar international studies" (M. Smoluchowski, 1917). Rudzki's other geographic studies include Odksztatcanie się ziemi pod ciężarem wielkich lodowców (Deformation of the Earth under the weight of large glaciers) (1899), O przepowiadaniu pogody (On weather forecasting) (1900), Teoria fizycznego stanu kuli ziemskiej (Theory of the physical state of the Earth) (1900), and Wypadki spostrzeżéń meteorologicznych w Galicyi 1903 roku zestawione w c. k. Obserwatorium Krakowskiem (Cases of meteorological observations in Galicia 1903 summarised at the RE Observatory of Kraków) (1904).

Rudzki was also highly regarded as a populariser of science. He held lectures in physical geography and cosmography at Adrian Baraniecki's Higher Courses for Women (1896-1901). He was also a member of several Polish and foreign scientific associations, including the Kraków-based Academy of Arts and Sciences (from 1899). Rudzki died in Kraków on 22 July 1916 and was laid to rest at the Rakowicki Cemetery.

Acknowledgements. We thank K. Schlegel for his cooperation and significant help.

Edited by: K. Schlegel

\section{References}

Brzozowski, S. M.: Rudzki Maurycy Pius (1862-1916) [w:] Polski Sł ownik Biograficzny, 33, 53-55, Kraków, 1991/1992.

Dormus, K.: Maurycy Pius Rudzki i poczaţki geofizyki w Polsce i na świecie, Publications of the Institute of Geophysics Polish Academy of Sciences, M-18 (273), 9-27, 1996.

Dormus, K.: Fizyka Ziemi i jej światowe poczaţki w Uniwersytecie Jagiellońskim. Prace Geograficzne Instytutu Geografii i Gospodarki Przestrzennej Uniwersytetu Jagiellońskiego, 127, 7-30, 2011.

Dormus, K.: Maurycy Pius Rudzki - twórca polskiej geofizyki, Przeglad Geofizyczny, 58, z. 1-2, 67-79, 2013. 
Garlicka, K.: Maurycy Pius Rudzki a poczatki geofizyki na Uniwersytecie Jagiellońskim, Kwartalnik Historii Nauki i Techniki, 39, 61-69, 1994.

Good, G. (Ed.): Sciences of the Earth: an Encyclopedia of Events, People and Phenomena, Vol. 1: A-G, Vol. 2: H-Z, Garland Publishing, New York, 1998.

Guidoboni, E.: Earthquakes and Tsunamis in the past: a guide to techniques in historical seismology, Cambridge University Press, Cambridge, 2009.

Hanik, J.: Katedra Geofizyki UJ (1875-1919),Przeglad Geofizyczny, 31, 339-345, 1986.

Jackowski, A. and Sołjan, I.: Z dziejów geografii na Uniwersytecie Jagiellońskim (XV-XXI wiek), Instytut Geografii i Gospodarki Przestrzennej Uniwersytetu Jagiellońskiego, Kraków, p. 87, 9596, 103-104, 359, 2009.

Maj, S.: Życie i działalność naukowa M. P. Rudzkiego (1862-1916), Przegla̧d Geofizyczny, 33, 390-399, 1988.

Maj, S.: Naukowe osiagnięcia Maurycego P. Rudzkiego. Publications of the Institute of Geophysics Polish Academy of Sciences, M-18, 27-34, 1996.

Mazur, M. M.: Maurycy Pius Rudzki (1862-1916). W stulecie krakowskiej sejsmografii, Prace Komisji Historii Nauki PAU, 8, 211-235, 2007.

Ołpińska-Warzechowa, K.: Meteorologia i klimatologia w pracach profesora Maurycego Piusa Rudzkiego, Publications of the Institute of Geophysics Polish Academy of Sciences, M-18, 43-46, 1996.

Rudzki, M. P.: O stanie wnȩtrza Ziemi (On the status of the Earth's interior), Przegląd Powszechny, XXIII, 1-669, 1889.

Rudzki, M. P.: Skorupa Ziemi (The Earth's crust), Przegląd Powszechny, XXV, 1-600, 1890.

Rudzki, M. P.: Nieskolko zamieczanji po powodu teorii obrazowanja gor (A few comments on the theory of mountain formation), Zapiski Obszczestwa, XV, 165-177, 1890.
Rudzki, M. P.: Odkształcanie się ziemi pod ciężarem wielkich lodowców (Deformation of the earth under the weight of large glaciers), Bull. de l'Académie des Sciences de Cracovie, 176224, 1899.

Rudzki, M. P.: O przepowiadaniu pogody (On weather forecasting), Kosmos XXV, 578-591, 1900.

Rudzki, M. P.: Teoria fizycznego stanu kuli ziemskiej (Theory of the physical state of the Earth), Akad. Umiejętności, XXXVII, Kraków, 225-420, 1900.

Rudzki, M. P.: Wypadki spostrzez?eń meteorologicznych w Galicyi 1903 roku zestawione w Obserwatorium Krakowskiem (Cases of meteorological observations in Galicia 1903, Observatory of Kraków), Sprawozdania Akad. Umiejętności, 38, 1904.

Rudzki, M. P.: Fizyka Ziemi (Geophysics), Akad. Umiejetności, Kraków, 1-538, 1909.

Rudzki, M. P.: Physik der Erde, Tauchnitz, Leipzig, 1-584, 1911.

Rudzki, M. P.: Zasady meteorologii (Principles of Meteorology), Wende i Spółka, Warszawa, 1-161, 1917.

Rybka, E.: Maurycy Pius Rudzki. Życie i działalność. Muzeum Techniki. Stowarzyszenie Geodetów Polskich, 1-16, Warszawa, 1974.

Schröder, W.: History of Geophysics, Acta Geodaetica et Geophysica Hungarica, 45, 253-261, 2010.

Smoluchowski, M.: Maurycy Rudzki jako geofizyk, Kosmos, 41, 1-12, 105-119, 1917.

Staszewski, J.: Badania i teorie geograficzne w spuściźnie M. P. Rudzkiego. W setna̧ rocznicę urodzin, - Przeglą̧ Geograficzny, 34, 651-678, 1962.

Teisseyre, R. (Ed.): Stulecie Pierwszej Katedry Geofizyki, Instytut Geofizyki PAN, Warszawa, 1-201, Publications of the Institute of Geophysics, 273, 1996.

Wójcik, Z.: O Maurycym Piusie Tomaszu Rudzkim, Przegląd Geofizyczny, 33, 399-404, 1988. 